\title{
ACM Check Dams in Concrete Gutters for Recirculation Filters of Wastewater from Whiteleg Shrimp (Litopenaeus vannamei) Aquaculture in Southern Thailand
}

\author{
Jiroj Peerakeitkhajorn ${ }^{1,2}$, Wit Tarnchalanukit ${ }^{1,2}$, Kasem Chunkao ${ }^{1,2}$, Narouchit Dampin ${ }^{1}$, Onanong Phewnil ${ }^{1,2}$ \& \\ Boonjongrak Jeawtan ${ }^{2}$ \\ ${ }^{1}$ Department of Environmental Science, Faculty of Environment, Kasetsart University, Bangkok, Thailand \\ ${ }^{2}$ The King's Royally Initiated Laem Phak Bia Environmental Research and Development Project, The \\ Chaipattana Foundation, Phetchaburi Province, Thailand \\ Correspondence: Kasem Chunkao, Department of Environmental Science, Faculty of Environment, Kasetsart \\ University, Thailand. Tel: 6-62-579-2116. E-mail: prof.kasemc@gmail.com
}

Received: April 11, 2015

doi:10.5539/mas.v9n12p161
Accepted: June 9, 2015

URL: http://dx.doi.org/10.5539/mas.v9n12p161
Online Published: September 30, 2015

The research is financed by The Chaipattana Foundation and Eco-Science Community Research Group, Faculty of Environment, Kasetsart University, Thailand.

\begin{abstract}
The research was aimed to recirculate the treated wastewater from Whiteleg shrimp farms in following each other without interruption by using concrete gutters containing ACM (Assembled Constructed Materials) check dams as the filters. Among the 2-inch diameter of chipped-assembled-constructed materials, the ACM-Brick filter was the most effective rather than roof-tile, blocked cement, and rock, respectively. Three ACM-Brick check dams with 5 -m space between them were indicated as $47.3 \%$ treatment efficiency together with flow rates of 600 to $900 \mathrm{~L} / \mathrm{hr}$, and up to more $65 \%$ and $85 \%$ for fourth and fifth ACM-Brick check dams while the first and second dams found $13.0 \%$ to $28.4 \%$ efficiencies. Seemingly, irrespective of employing brick, roof-tile, blocked cement, or rock for constructing the ACM check dam was installed in concrete gutters with the size of $1-\mathrm{m}$ width, $0.5-\mathrm{m}$ depth, and more or less $20-\mathrm{m}$ length that could be served needs in recirculation aquaculture of Whiteleg shrimps to gain satisfied benefits. Culturing Whiteleg shrimps in 3-sq.m. and 3-cu.m.concrete gutters containing only one of 0.5-sq.m. and 1-depth ACM-Brick filters by RCB design for 4 treatments (culturing shrimp densities) and 3 replications found the density of 105 juveniles $/ 3 \mathrm{~m}^{2}(6,606 \mathrm{~kg} / \mathrm{ha})$ with the most harvested-added weight 2,710 $\mathrm{kg} / \mathrm{ha}$ ( $69.55 \%$ of beginning weight), and decreasing after increasing the density of $6,720,8,371$, and 11,382 $\mathrm{kg} / \mathrm{ha}$ in corresponding to harvested-added weight $65.29 \%, 46.36 \%$, and $42.33 \%$, respectively. The findings also informed that flow rate of $720 \mathrm{~L} / \mathrm{hr}$ indicated somewhat high effective influences on decreasing of water temperature, salinity, $\mathrm{pH}, \mathrm{DO}, \mathrm{EC}$, alkalinity, TDS, $\mathrm{BOD}, \mathrm{NH}_{4}-\mathrm{N}, \mathrm{NO}_{2}-\mathrm{N}$, and $\mathrm{NO}_{3}-\mathrm{N}$ which were conditioned for recirculation aquaculture of Whiteleg shrimps.
\end{abstract}

Keywords: check dam, recirculation filters, Whiteleg shrimp, aquaculture

\section{Introduction}

\subsection{Background}

Look back before 1960, there were plenty of marine animals in the Gulf of Thailand and Andaman strand line which could be properly caught for day-to-day food availability, not only without any shortage in supplying but also no toxic contaminant existences. Until the year of 1970, the marine animals, especially shrimps, fishes, crabs, clams, mussels, shells, and octopuses, have been rapidly decreased due to overfishing by explosive population in all fishing parts of the country, and also over-exporting in form of fresh and canned goods for monetary profits needs of serving national socioeconomic development. Consequently, the rapid decrease of the marine lives was covered in the whole areas of the Gulf of Thailand and coastal zone of Andaman sea that enhanced the directednegative impacts on foodstuff and local and national incomes. For solving such problem, the government has made the G-to-G Fish Catching Contacts with the neighboring countries such as Burma, Indonesia, Vietnam, 
Bangladesh, and others in order to have more opportunities to catch the sharing marine lives as the main raw products for frost and dry foodstuff, canned fishes, and ready-cooking food. At the same time since the year of 1980, the toxic contaminants of pesticides, herbicides, fungicides as much as industrial pollutants in freshwater and spreading to marine water in some strand-line areas that could be another cause to retard such renewable catching marine lives.

Exactly, the marine animals are not only important but all necessary for local consumption approximately $20 \mathrm{~kg} /$ person (total catching about 3.3 million tons/yr) due to high protein sources to provide for all parts of Thailand. Among all kinds of marine animals as used for food stuff, marine shrimps are favorable rather than fishes, shells, mussels, crabs, octopuses, jellyfishes, etc. owing to no others to compete with much more protein contents along with its soft meat and good taste. Also, frozen and processed shrimp are exported approximately 80,000 tons/yr to US, 70,000 tons/yr to Japan, 50,000 tons/yr to EU, and 10,000 tone/yr to our neighboring countries which could gain over 3,000 million US dollars per annum. Surely, overfishing was taken place in the Gulf of Thailand and Andaman coastal zone that made decreasing of natural shrimp products for only local consumptive use and not excess for exporting to any countries but some small part being sent to neighboring countries, especially Lao RPD and Cambodia. Consequently, the sanitary-based shrimp aquaculture has been promoted in order to produce more products enough for local consumption and exporting frozen-processed shrimps. Fortunately, Thailand is located in tropical climate that provides for shrimp culture, especially in the eastern, central, and southern areas. This is why the shrimp aquaculture all together more than 10,000 farms which can produce shrimp more than 100,000 tons/yr. Accordance with temptation of possible culturing and better income that was encouraged to produce the shrimp culture in the central, the east, the south, the eastern side on the Gulf of Thailand, and the south in the Andaman sea. It would be pretty to inform that most of the shrimp culture farms drained the wastewater with high organic matter concentration after harvesting the products to the public marine water, particularly along the seashore, causing marine and/or estuarine water pollution. Besides, the outbreaks of shrimp epidemics have been encountered in every part of the country that made numerous decreasing of shrimp farms approximately 50 percentages, especially decreasing more than 50 percentages in southern Thailand. In facts, the treated shrimp-farm wastewater is really needs to eliminate organic matters as well as all toxicchemical forms of nitrogen, phosphorus, carbon, sulfur, and some toxic chemicals and elements (Khan et al, 2009; Wu \& Yang, 2011; Erler et al., 2004, Cahu et al., 2012; Burford et al., 2004; Cohen et al., 2005; Prapaiwong \& Boyd, 2012, Casillas-Hernandez et al., 2007; Carvalho et al., 2013; Martins et al., 2010; Mook et al., 2012; Tilley et al., 2002; Mariscal-Lagarda et al., 2012; Green \& Ward, 2011)

Nowadays, wastewater treatment from shrimp farms are obligate needed to conduct before draining out to shoreline without any contamination of organic matters and toxicants in seawater. There have been various methods on how to treat shrimp-farm wastewater before releasing to the seawater sources, such as dilution, lagoon, oxidation pond technology, mangrove forest filtration, and constructed wetland technology (Tilley et al., 2002; Sklarz et al., 2009; Green \& Ward, 2011; Chunkao et al., 2012; Mariscal-Lagada et al., 2012; Chunkao et al., 2014; Phewnil et al., 2014) but they were in doubted issue on efficiency and disease contamination. Because of such constraints, the advanced techniques were employed to treat wastewater from shrimp farms such as electrochemical technology (Mook et al., 2012), low-salinity shrimp farming (Prapaiwong et al, 2012), outdoor tank shrimp wastewater recirculation system (Lavania-Baloo et al., 2014), limited discharge and biosecure management tool (Cohen et al., 2005), zero-water exchange culture tanks (Xu et al., 2012), high-intensively zero-exchange system (Burford et al., 2004), integrated culture with low salinity groundwater (Mariscal-Lagarda et al., 2012), semi-intensively managed shrimp pond waters (Green\&Ward, 2011), EU recirculating aquaculture systems (Martins et al., 2010), culture ponds utilizing two different feeding strategies (Carrillo-Hernandez et al., 2007), and others. These approaches are exactly expensive and delicate to operate both during and after constructing, particularly to control the food residues as the main point sources of wastewater from shrimp ponds. Also, continuity of producing shrimps could not be existed due to cleaning the ponds after harvesting, except some approaches concerning with recirculation system for intensive aquaculture.

Actually, H.M. the King of Thailand has initiated the irrigation technique in the year of 1970 to rehabilitate wastewater from shrimp ponds before releasing to the sea to prevent polluting in marine water along the coastlines. Actually, this Royal technique could be applied for treating organic wastewater from shrimp farms located close to mangrove forest by pumping through HPDE pipe far from shoreline about $5 \mathrm{~km}$ in order to dilute the high concentration of organic wastes from shrimp farms with high dissolved oxygen (DO)-concentrated seawater, and enhancing on rapidly bacterial organic digestion processes to enrich plant nutrients for growing phytoplankton as marine animal food. It has been observed that there is very less shrimp farms in need of the Royal technique due to high expenses as well as getting some difficulty to combine the dispersed shrimp farms for 
constructing irrigation canals and connecting HPDE pipe to transfer shrimp farm wastewater to about $5 \mathrm{~km}$ in marine site far from the shoreline.

In order to support the individual shrimp farm, the assembled-constructed-material check dam in concrete gutter (ACM-CDCG) technology as recirculation filters is proposed to treat wastewater before carelessly draining into public seawater sources. The ACM-CDCG technology is simply made of assembling the constructed materials (such as small chips of brick, blocked concrete, rock/gravel, broken cement, and roof tile) to be piled up perpendicular to the concrete gutter in check-dam form under the obligations of $45^{\circ}$-sloped side on upstream and $30^{\circ}$-sloped inclination on downstream areas to decrease the shrimp farm organic wastes in terms of biological oxygen demand (BOD), chemical oxygen demand (COD), total dissolved solids (TDS), total suspended solids (TSS), turbidity, and compounds of N,P,C, and $\mathrm{S}$ in proper conditions of $\mathrm{pH}$, and salinity as well as flow velocity and concentration of organic contaminants.

However, it is presumable to exist the aerobes and anaerobes adhering around the surface of those chips of constructed materials which will take in action of organic digestion processes by aerobic bacterial due to free oxygen availability on wastewater surface, and by anaerobic bacteria due to extracted oxygen from oxygen-incompound organic matters. (Metcaft \& Eddy Inc., 1974; Andrian \& Sanders, 1998; Green \& Ward, 2011; Clesceri et al., 1998; Borkar \& Mahatime, 2011, Vymazal, 2010, Umidla \& Ademoroti, 2012; Uwidia \& Ukulu, 2013; Tchnobanoglous \& Kreiti, 2002; Padgett, 1978; Padgett, 1975; Sah et al., 2011; Srivastav \& Avasthi, 1975; Mispagel \& Gray, 2005). It is expected to decrease the maximum concentration of BOD, COD, TDS, TSS, and turbidity from shrimp farms around the country.

Here, we aim to design the concrete gutters as the experimental units laying down on the ground surface in the open uniform site that being available to wind blowing, direct solar radiation, and no shading in order to apply the King's initiative nature-by-nature process for full supporting bacterial organic digestion process together with photosynthesis of green phytoplankton and another algae species.

\subsection{Area Description}

The experimental site is settled inside Rajamagala University of Technology Srivijaya, Trang campus which located along the shoreline of Andaman sea in Trang Province, the south as shown in Figure1. The whole area coverage of Trang province is approximated $30,000 \mathrm{~m}^{2}$, being composed of mountainous cover $35 \%$, rugged terrain $25 \%$, flatland $20 \%$, mangrove forest $10 \%$, muddy beach $5 \%$, sand beach $4 \%$ and island 1\%. Among 3.5 million people are belonged to occupation in fisheries about $30 \%$, rubber tree plantation $35 \%$, shrimp farms $20 \%$, tourism services $10 \%$, traders $4 \%$ and others $1 \%$. The annual income per capita is evaluated above 100,000 baht, better than the national income per head about 10,000 baht/annum, but it is depended the market price of para rubber rather than anything else. Although the marine-animal catching occupation is not main income, it provides enough for local consumption. Remarkably, shrimp aquaculture is another protein food as paid role not only local supplement but also to support tourism activity.

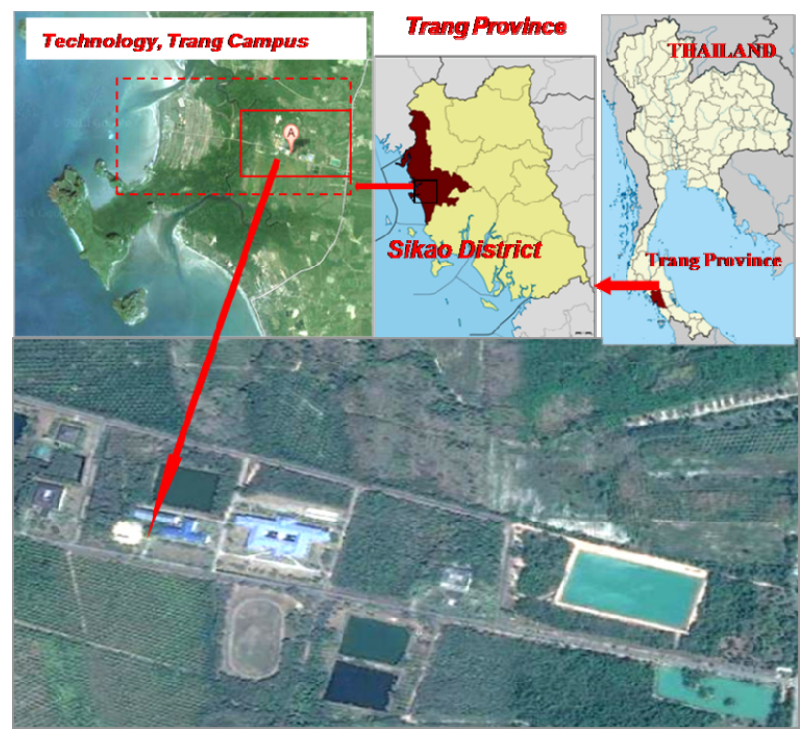

Figure 1. Experimental site localized inside of Rajamagala University of Technology Srivijaya, Trang province in Southern Thailand 
Actually, Trang provincial area is characterized as the tropical rainforest in southern Thailand together with always green cover, mostly para rubber tree plantation and forest due to at least 8-month rain falling (average annual rainfall $1,800 \mathrm{~mm}$ ) and really dry period not more than 3 months. The daily differenttemperature between maximum and minimum is less than $8.0^{\circ} \mathrm{C}$ (with extreme maximum at $38^{\circ} \mathrm{C}$ and extreme minimum $23^{\circ} \mathrm{C}$ ) while the average value of annual relative humidity is around $65 \%$ with extreme $50 \%$ as well as the sunshine period about 8 hours/day (see Table 1).

Table 1. Climatic data as measured at Muang district of Trang province far away from Rajamagala University of Technology Srivijaya, Trang campus during 1963-2012

\begin{tabular}{|c|c|c|c|c|c|c|c|c|c|c|c|c|c|c|}
\hline Month & 1999 & 2000 & 2001 & 2002 & 2003 & 2004 & 2005 & 2006 & 2007 & 2008 & 2009 & 2010 & 2011 & 2012 \\
\hline Jan. & 134.10 & 65.5 & 256.8 & 1.3 & 26.9 & 0.0 & 7.7 & 44.8 & 73.3 & 22.9 & 35.4 & 45.9 & 123.2 & 112.7 \\
\hline Feb. & 108.90 & 65.5 & 17.2 & 0.0 & 0.0 & 36.1 & 10.8 & 20.7 & 3.1 & 38.3 & 0.0 & 38.2 & 2.6 & 22.5 \\
\hline Mar. & 180.30 & 214.1 & 184.8 & 73.7 & 43.6 & 89.4 & 16.1 & 65.2 & 164 & 73.9 & 221.6 & 24.3 & 448.7 & 184.2 \\
\hline Apr. & 196.50 & 135.4 & 133.5 & 116.6 & 38.5 & 57.8 & 33.4 & 177.3 & 212.7 & 181.9 & 148.9 & 132.7 & 122.5 & 256.8 \\
\hline May & 226.30 & 320.9 & 251.5 & 200.9 & 208.6 & 128 & 282.3 & 365.3 & 187.5 & 194.8 & 159.6 & 148.6 & 156.3 & 238.0 \\
\hline Jun. & 180.20 & 318.8 & 111 & 101.5 & 135.6 & 426.6 & 201.5 & 279.4 & 275.1 & 245.2 & 69.3 & 295.5 & 106 & 280.2 \\
\hline Jul. & 177.00 & 149.1 & 246.7 & 133.7 & 274.4 & 444.9 & 252.8 & 341.8 & 272.0 & 123.8 & 241.4 & 229.4 & 331.2 & 315.0 \\
\hline Aug. & 236.60 & 295.6 & 170.1 & 230.1 & 341.5 & 117.7 & 102.4 & 303.5 & 285.0 & 98.8 & 251.6 & 146.7 & 208.5 & 228.4 \\
\hline Sep. & 469.60 & 373.1 & 226.4 & 316.0 & 214.1 & 273.5 & 98.0 & 191.5 & 330.3 & 238 & 328.1 & 301.5 & 299.3 & 385.0 \\
\hline Oct. & 438.70 & 315.7 & 212.1 & 205.4 & 284.2 & 160.2 & 247.9 & 100.8 & 412.5 & 323 & 338.8 & 241.3 & 167.0 & 168.0 \\
\hline Nov. & 179.10 & 348.4 & 140.5 & 127.5 & 183.5 & 68.5 & 286 & 78.2 & 157 & 184 & 303.3 & 544.6 & 231.5 & 200.8 \\
\hline Dec. & 109.00 & 71.8 & 255.3 & 130.9 & 79.2 & 58.4 & 494.2 & 30.1 & 79.6 & 56.8 & 19.2 & 194 & 138.6 & 187.5 \\
\hline
\end{tabular}

\section{Method}

\subsection{Selecting Constructed Materials for Single ACM Check Dam}

This research aimed to select from four kinds of the eligible chipped materials of roof tile, rock, brick,and blocked cement (as divided into 4 treatments and 3 replications) in order to make the assembled-constructed materials (ACM) check dam as filters for treating wastewater from Whiteleg shrimp aquaculture by recirculation treated wastewater. For fulfillment of research objectives, the twelve $3.5 \mathrm{~m}^{3}$ concrete gutters in size of $1-\mathrm{m}$ width, $1-\mathrm{m}$ depth, and 3.5-m length were constructed by dividing into two portions of $0.5 \mathrm{~m}^{3}(1 \times 1 \times 0.5 \mathrm{~m})$ for filling 2-inch chips of roof-tile, rock, brick, and blocked cement by filters; and the second one, the 3-cu.m. for concrete gutter for recirculating filtrated wastewater from Whiteleg shrimp aquaculture as shown in Figure 2.

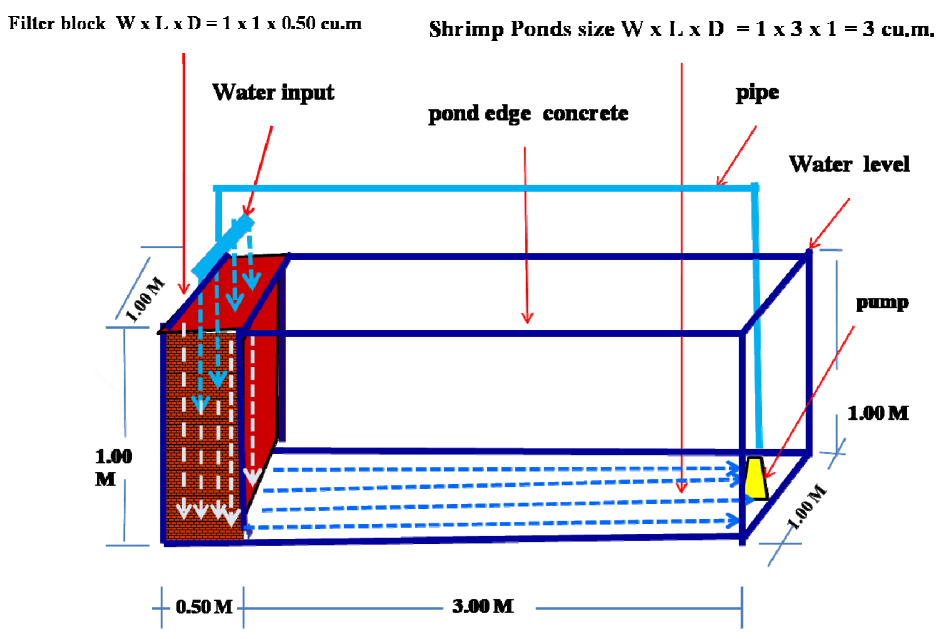

Figure 2. Structures of concrete gutter divided into two portions; filter part containing $0.5 \mathrm{~m}^{3}$ of constructed materials and $3 \mathrm{~m}^{3}$ for Whiteleg shrimp aquaculture. Both parts are connected by pipes with pumping for recirculating treated wastewater 
The bottom part of $0.5 \mathrm{~m}^{3} \mathrm{ACM}$ filters were opened to drain the treated wastewater into concrete gutters for Whiteleg shrimp aquaculture. Also, at the bottom and the tip of the $3 \mathrm{~m}^{3}$ portion for aquaculture was made a small space in rectangular gutter for draining out wastewater to pipe by pumping into ACM filters in order to retreat as illustrated in Figure 2. The flow rate was designated in $480 \mathrm{~L} / \mathrm{hr}$ for all ACM filters in order to make fairly comparable for selecting the proper constructed materials (roof-tile, rock, brick, and blocked cement). To estimate the water quality of treated wastewater, water temperature, salinity, $\mathrm{pH}$, electrical conductivity (EC), alkalinity, DO, TDS, BOD, ammonium nitrogen $\left(\mathrm{NH}_{4}{ }^{-} \mathrm{N}\right)$, nitrite nitrogen $\left(\mathrm{NO}_{2}-\mathrm{N}\right)$, and nitrate nitrogen $\left(\mathrm{NO}_{3}-\mathrm{N}\right)$ of initial influents and the effluents were measured every week throughout the experiment ( 5 weeks).

\subsection{Selecting Appropriate Flow Rate for Single ACM Check Dam}

This experiment was conducted to estimate suitable flow rate of treated wastewater from Whiteleg shrimp culture in the concrete gutters with $0.5 \mathrm{~m}^{3}$ of ACM filters, which were same size as the previous experiment. Four flow rate of wastewater influent $(240,480,720$ and $960 \mathrm{~L} / \mathrm{hr})$ were varied, afterwards, water quality indicators were collected at the beginning and every week throughout the experiment (5 weeks).

\subsection{Applicable ACM Check Dam and Its Probable Numbers}

To confirm the capability of selected ACM for check dams, we also investigated the numbers of ACM check dam for effective treatment. Due to the previous statement, the statistical method could be taken in one from five of ACM check dams in 12-m concrete gutters, and one from four discharges $(300,600,900$, and 1,200 L/hr). By means of previous plans, the Randomized Complete Block Design (RCBD) was employed for 4 treatments (4 kinds of constructed materials) and 3 replications ( 3 concrete gutters, and each gutter containing 5 ACM check dams with designating 6 measuring points for wastewater quality as illustrated in Figure 3.

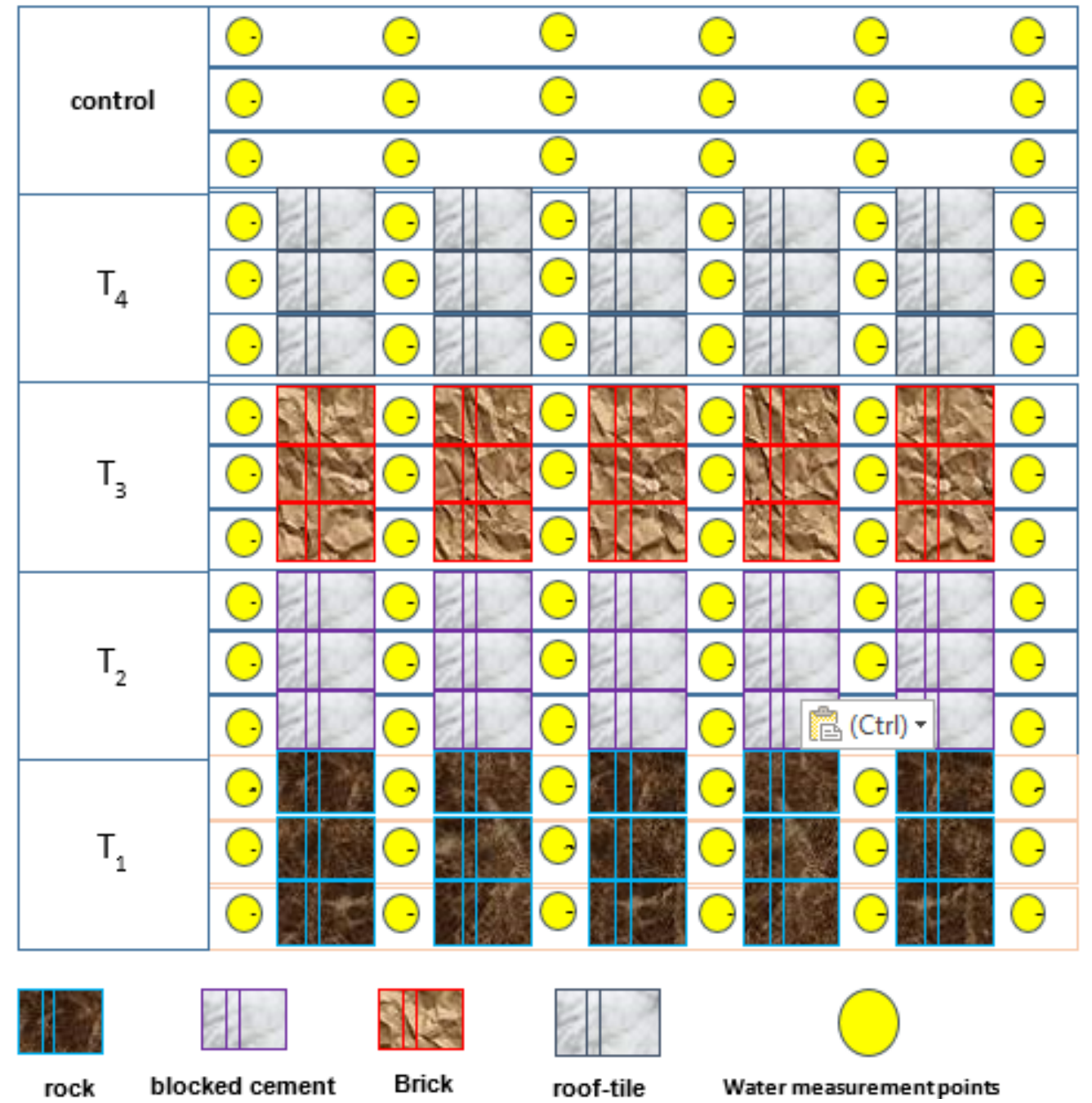

Figure 3. RCBD for 4 sets of 5 treatments ( 4 kinds of constructed materials and 1 control) and 3 replications ( 3 concrete gutters for each treatment) in order to experiment for 4 discharges $(300,600,900$, and 1,200 L/hr) 
The experiments were started draining shrimp-farm wastewater with flow rates of $300,600,900$, and 1,200 L/hr at the same time through each concrete gutters containing 5 ACM check dams as assembled by small chips of rocks, blocked concretes, red bricks, roof tiles, and controls). Water samples were taken at point 1 (influent in front of ACM check dam1), point 2 (effluent after ACM check dam 1), point 3 (effluent after ACM check dam 2), point 4 (effluent after ACM check dam 3), point 5 (effluent after ACM check dam 4), point 6 (effluent after ACM check dam 5) as shown in Figure3, in order to analyze the gradually decreasing wastewater concentration in terms of water quality indicators of BOD, TDS, total suspended solids (TSS), alkalinity, $\mathrm{NH}_{4}-\mathrm{N}, \mathrm{NO}_{3}-\mathrm{N}$, bacteria in biofilm, $\mathrm{pH}$, water temperature, electrical conductivity, dissolved oxygen, and salinity by the methods of APHA.AWWA.WEF (2005). After that, the efficiencies of wastewater treatments from shrimp farms of each environmental indicator were calculated to choose the most probable kind of constructed material, numbers of ACM check dam, and influent flow rates. It should be noted here that the average saline water as used for local shrimp aquaculture will be taken in designating as the natural standard values in comparison with the treated wastewater values for determining efficiency wastewater treatment by proper constructed material and its ACM check dam in relation to influent flow rates.

\subsection{Aquaculture of Whiteleg Shrimps}

The selected ACM check dam and designating flow rate would be applied for Whiteleg shrimp aquaculture in relation between its growth rate and wastewater treatment efficiency. In all probability, the numbers of Whiteleg shrimps per aquaculture unit has been found the criterion in polluting water of shrimp pond rather than anything else. So, the RCBD (see Figure 4) was employed for experimenting to feast 2,520 Whiteleg shrimp juveniles (averaged weight $20 \mathrm{~g}$ each) with 4-level densities (4 treatments) and 3 replications (3 ponds each) in total of 12 ponds $\left(3 \mathrm{~m}^{3}\right.$ capacity each) the details as follows:

Treatment 1: 105 juveniles $/ 3 \mathrm{~m}^{2}$ in 3 ponds, total 315 juveniles,

Treatment 2: 175 juveniles $/ 3 \mathrm{~m}^{2}$ in 3 ponds ,total 525 juveniles,

Treatment 3: 245 juveniles $/ 3 \mathrm{~m}^{2}$ in 3 ponds, total 735 juveniles,

Treatment 4: 315 juveniles $/ 3 \mathrm{~m}^{2}$ in 3 ponds, total 945 juveniles,

Normally, the culturing juvenile shrimps were feed 3 times a day but it depends on the density and aging periods. Food in tablet form was put on feeding tray and fastening with long rope in order to lay down on concrete gutter beds for eating convenience. The influent (effluent from feasting concrete gutters) and effluent of concrete gutters containing ACM check dams for wastewater treatment from feasting concrete gutters of Whiteleg shrimp aquaculture were also collected at the beginning and every week for analyzing their water quality in terms of indicators in order to determine the wastewater treatment efficiencies. In addition, the growth rates and survivals of Whiteleg shrimp juveniles were conducted in every 15 days (total 5 times) within 3-month period in order to relate to wastewater quality levels.

Then after, the influent (effluent from feasting concrete gutters) and effluent of concrete gutters containing ACM check dams for wastewater treatment from feasting concrete gutters of Whiteleg shrimp aquaculture will be also collected for analyzing their water quality in terms of indicators in order to determine the wastewater treatment efficiencies.
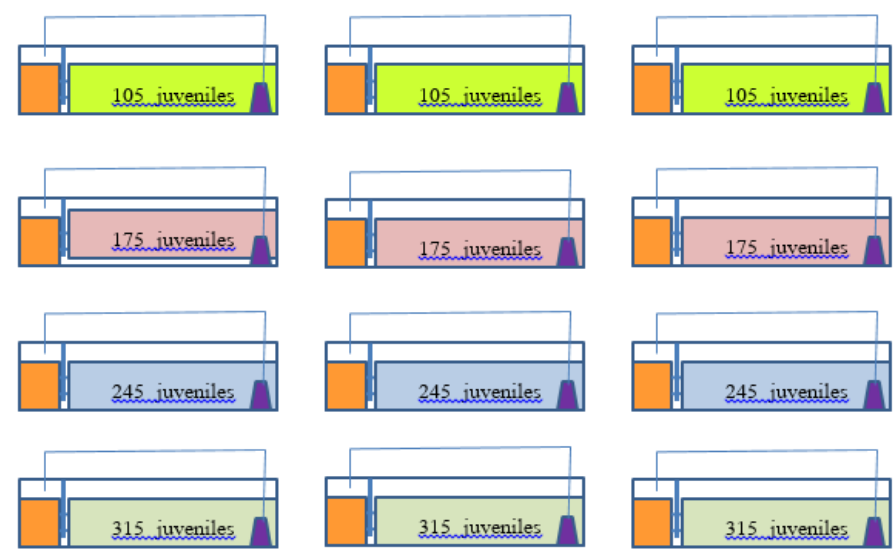

Figure 4. RCBD for experimenting to feast on 4 treatments (feasting 4-level densities) and 3 replications (3-ponds of each feasting level density) in $3 \mathrm{~m} 3$ ponds together with recirculation as filters through selected ACM check dams in concrete gutters 


\subsection{Analysis of Water Quality Indicators}

The growth rates and survivals of Whiteleg shrimp juveniles will be conducted in every 10 days (total 11 times) within 3-month period in order to relate to wastewater quality levels in relation to collect the wastewater quality samples.

\subsection{Experimental Periods}

The experimental periods were taken in one year during February 2010 to December 2014 which includes 7 phases as follows:-

Phase1: Experimental design during January 2008 to February 2008.

Phase 2: Site preparation during March 2008 to May 2008.

Phase 3: Construct the 3.5-cu.m. Concrete gutters by divided into 1x1x0.5-m for ACM filters, and $1 \mathrm{x} 1 \mathrm{x} 3 \mathrm{~m}$ for Whiteleg shrimp aquaculture during June 2008 to December 2010.

Phase 4: Construction of concrete gutters and ACM check dams during June 2008 to July 2009.

Phase 5: Feasibility study on concrete gutters containing ACM check dams during August 2009 to January 2010.

Phase 6: Experiments for selecting constructed materials and ACM check dams during February 2010 to December 2010 and reconfirmation of experiments during September 2010 to September 2014.

Phase 7: Experiments for Whiteleg shrimp aquaculture by employing the concrete gutters containing selected constructed materials, ACM check dam, and flow rate during January 2010 to November 2010.

\section{Results and Discussion}

Owing to the research is attempted to recirculate the treated wastewater from Whiteleg shrimp ponds in following each other without interruption by using concrete gutter together with containing ACM check dams as the filters (1 $\mathrm{m}$ in width, $1 \mathrm{~m}$ in depth and $0.5 \mathrm{~m}$ in length). Firstly, the most proper chipped-ACM (roof tile, rock, brick, and blocked cement) have to determine in order to use in large-scale experiments. Anyhow, the following section will be formalized in consecutive presentations as follows:-

\subsection{Applicable Water Quality Indicators for single ACM Check Dam}

The research plan was hypothesized to employ the 11 water quality indicators, i.e., water temperature, salinity, $\mathrm{pH}, \mathrm{EC}, \mathrm{DO}, \mathrm{TDS}, \mathrm{BOD}, \mathrm{NH}_{4}{ }^{-} \mathrm{N}, \mathrm{NO}_{2}-\mathrm{N}$, and $\mathrm{NO}_{3}-\mathrm{N}$ in which they could exactly go hand in hand with ACM check dams as filters. Only selecting 2-inch-diameter chips of assembled-constructed materials (roof tile, rock, brick, and blocked cement) were conducted the 4 flow-rates of 240, 480, 720, and $960 \mathrm{~L} / \mathrm{hr}$ passing through the block filters $(1 \times 1 \times 0.5 \mathrm{~m})$ as assembled by 3 replications in each of roof-tile, rock, brick, and blocked-cement (4 treatments) in which the filtered blocks were allocated to the head of 3-cu.m. concrete gutters as shown in Figure 2. The results of experiments were presented in Figure 5 and Table 2.
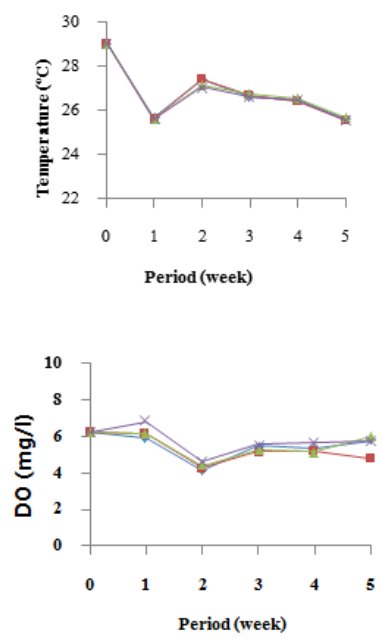
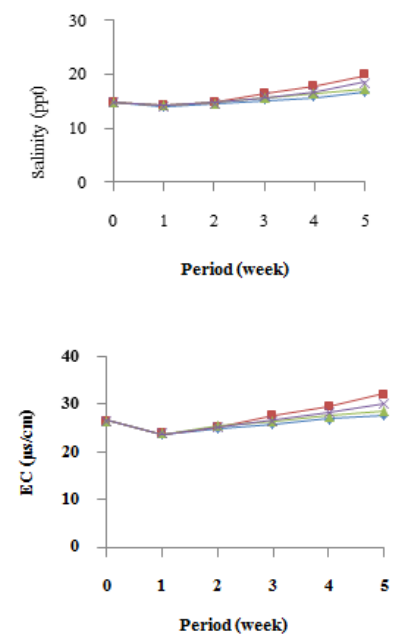
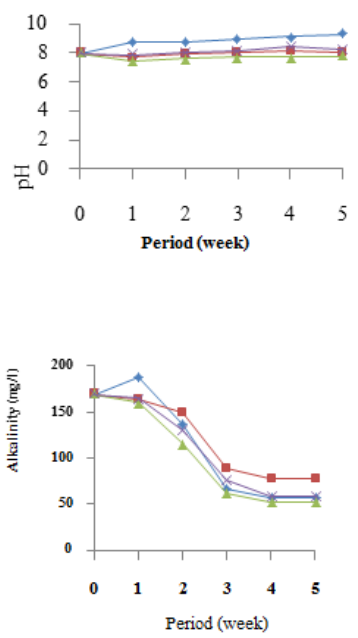

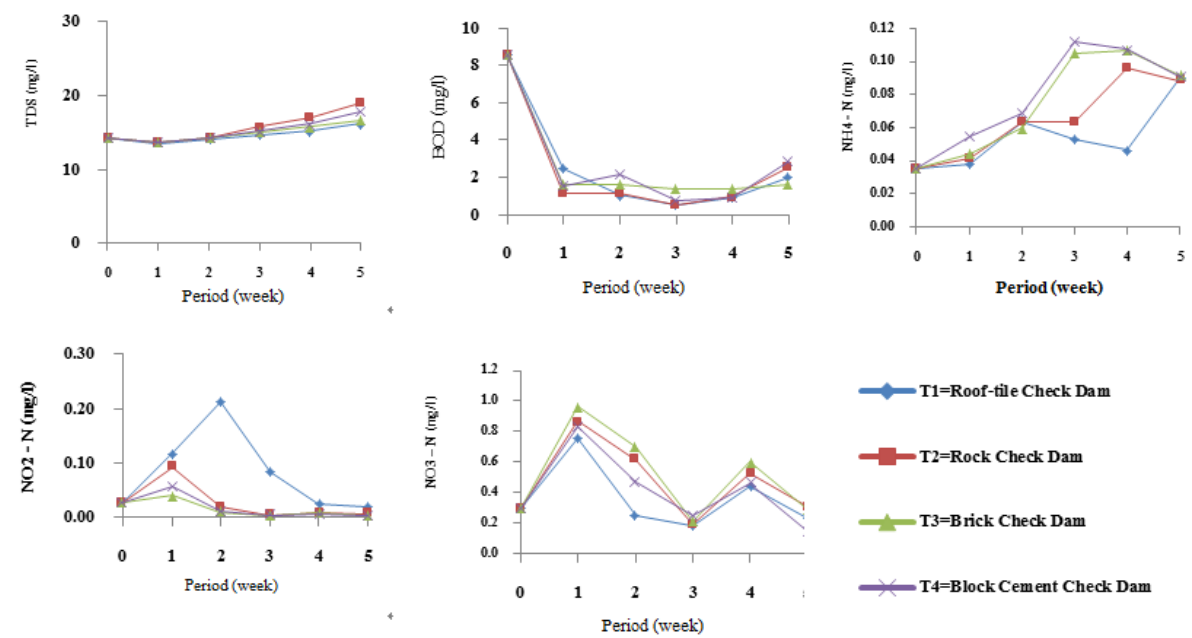

Figure 5. Decreasing trends of eleven water quality indicators after flowing wastewater of $480 \mathrm{~L} / \mathrm{hr}$ through the four kinds of assembled-constructed filters (roof tile, rock, brick, blocked cements) for 5-week recirculation aquaculture of Whiteleg shrimps

Table 2. Averaged ranges of eleven water quality indicators after flowing wastewater of $480 \mathrm{~L} / \mathrm{hr}$ through the four kinds of assembled-constructed filters (roof tile, rock, brick, blocked concrete) for 5-week circulation aquaculture of Whiteleg shrimps

\begin{tabular}{|c|c|c|c|c|}
\hline \multirow[t]{2}{*}{ Indicator } & \multicolumn{4}{|c|}{ Constructed Materials } \\
\hline & Roof-tile & rock & brick & Blocked cement \\
\hline Temperature $\left({ }^{\circ} \mathrm{C}\right)$ & $25.2-29.0$ & $25.3-29.1$ & $25.3-28.9$ & $25.2-29.2$ \\
\hline Salinity (ppt) & $14.0-17.83$ & $14.2-21.20$ & $14.2-18.33$ & $14.20-19.80$ \\
\hline $\mathrm{pH}$ & $8.2-9.3$ & $7.7-8.1$ & 7.8-7.4 & 7.9-8.4 \\
\hline $\mathrm{DO}(\mathrm{mg} / \mathrm{L})$ & $4.2-5.9$ & $4.1-6.2$ & $4.4-6.2$ & $4.6-6.8$ \\
\hline $\mathrm{EC}(\mu \mathrm{s} / \mathrm{cm})$ & $23.5-29.0$ & $23.8-34.0$ & $23.8-29.8$ & $23.8-31.9$ \\
\hline Alkalinity $(\mathrm{mg} / \mathrm{L})$ & $57-189$ & $87-183$ & $52-160$ & $59-165$ \\
\hline TDS (mg/L) & $13.5-17.1$ & $13.7-20.3$ & $13.7-17.6$ & $13.7-19.0$ \\
\hline $\mathrm{BOD}_{5}(\mathrm{mg} / \mathrm{L})$ & $0.5-7.4$ & $0.6-9.1$ & $1.1-7.9$ & $0.8-9.7$ \\
\hline $\mathrm{NH}_{4}-\mathrm{N}(\mathrm{mg} / \mathrm{L})$ & $0.036-0.090$ & $0.034-0.143$ & $0.036-0.106$ & $0.034-0.112$ \\
\hline $\mathrm{NO}_{2}-\mathrm{N}(\mathrm{mg} / \mathrm{L})$ & $0.019-0.211$ & $0.004-0.093$ & $0.003-0.040$ & $0.003-0.057$ \\
\hline $\mathrm{NO}_{3}-\mathrm{N}(\mathrm{mg} / \mathrm{L})$ & $0.134-0.756$ & $0.188-0.870$ & $0.207-0.962$ & $0.147-0.832$ \\
\hline
\end{tabular}

In earlier statement on area description concerning with climate in Trang province is exactly classified as rain forest condition of tropical climate with less different maximum and minimum air temperature, and also about 8-month heavy rain along with high humid all the year. The said phenomena brings reflect to water quality of both freshwater and seawater by dilution process between rainwater and polluted water from shrimp farms, households, restaurants, factories, croplands, and transportation. There was no surprising why the average temperature of Whiteleg shrimp cultural wastewater effluents passing through the 2-inch-diameter ACM filters of roof tiles, rocks, bricks, and blocked cements were quite narrow ranges throughout the periods of aquaculture (see Table 2). It should be noted that the water temperature in Whiteleg shrimp cultural concrete gutters $\left(3 \mathrm{~m}^{3}\right.$ each) were disorderly varied from week to week of conducting the aqua-culturing but it depended on falling rainwater temperature (see Figure5). Summarily speaking, there was no difference in water temperature after treating by small-chipped AC filters of roof tiles, ricks, bricks, and blocked cements. Therefore, water temperature cannot be employed for selecting the proper ACM check dam. Salinity of Whiteleg shrimp wastewater in concrete gutters trended to increase after culturing 2 weeks and being gradually increased up to the fifth weeks with averagedrange values of 14.87-17.83 ppt, 14.23-21.20 ppt, 14.23-18.33 ppt, 14.20-19.80 ppt after AC filtration of roof tiles, rocks, bricks, and blocked cements, respectively, due to the higher-density seawater which characterized as low-density rainwater on the surface which used for 5-week culturing. By overall image, the salinity from the beginning to the end of Whiteleg shrimp aquaculture could not be different enough to apply for selecting ACM check dam. In addition, $\mathrm{pH}, \mathrm{EC}, \mathrm{DO}$, and TDS found the narrow differences between the minimum and maximum 
values like water temperature and salinity as indicated in Table 2 and Figure5. In contrary, disordering fluctuation of $\mathrm{NH}_{4}-\mathrm{N}, \mathrm{NO}_{2}-\mathrm{N}$, and $\mathrm{NO}_{3}-\mathrm{N}$ as $\mathrm{ACM}$ filters (roof tiles, rocks, bricks, and blocked cements were found during the first throughout the final week of aquaculture periods in which these three water quality indicators should not be considered neither in selecting ACM check dam. BOD was shown in high confident-applicable water quality indicator for selecting the ACM check dam as well as determining its treatment efficiency which resembled the results of Tilley et al. (2002); Mook et al. (2012); Martins et al. (2010); Carvalho et al. (2013); Prapaiwong \& Boyd (2012); Burford et al. (2004); and Xu et al. (2012).

Owing to comparison among AC filters (roof tiles, rocks, bricks, and blocked cements) and Whiteleg shrimp wastewater quality indicators in terms of ranking, the results found that the AC brick filter was the best alternative, $\mathrm{AC}$ roof-tile the second, $\mathrm{AC}$ blocked cement filter the third, and $\mathrm{AC}$ rock filter the last. In practical point of view, they played vital role in not only filters but also forwards to ACM check dam for Whiteleg shrimp wastewater treatment. It was observed that the small chips with rough surface was pronounced for having high efficiency in ACM filter and expecting towards ACM check dam due to more areas for bacterial adherence and in turn to enhance the bacterial organic digestion processes equivalent to increase the filtration efficiency.

Theoretically points of view, water quality is the most important in shrimp aquaculture, especially the indicators of water temperature, salinity, $\mathrm{pH}, \mathrm{DO}, \mathrm{EC}$, alkalinity, TDS, $\mathrm{BOD}, \mathrm{NH}_{4}-\mathrm{N}, \mathrm{NO}_{2}-\mathrm{N}$, and $\mathrm{NO}_{3}-\mathrm{N}$ in which they were analyzed as presented in averaged value in Table 3 and Figure 6 . The identified results showed that the flow rates of $240,480,720$, and $960 \mathrm{~L} / \mathrm{hr}$ can get along each other quite well with very narrow changes of each water quality indicator (see Figure 6). After close looking at the trends of each water quality indicators (emphasizing on $\mathrm{pH}$, salinity, $\mathrm{DO}, \mathrm{EC}$, alkalinity, TDS, $\mathrm{BOD}, \mathrm{NO}_{2}-\mathrm{N}$, and $\mathrm{NO}_{3}-\mathrm{N}$ ), the flow rate of $720 \mathrm{~L} / \mathrm{hr}$ was seemingly shown in more influences than the others. The probable HRT would be better reasoned for nitrosomonas and nitrobacteria to take an account with bacterial organic digestion processes as well as the open concrete gutters to enhance the vertical flow by thermo-siphon process due to evaporation process as described by Streeter and Phelps (1925), Metcalf and Eddy Inc.(1974), Padgett (1975; 1978), Andrian \& Sanders (1998), Green and Ward (2011), Clesceri et al. (1998), Srivastav \& Avasthi (1975), and Mispagel \& Gray (2005). For the flow rate of $960 \mathrm{~L} / \mathrm{hr}$, it could be a little fast that made shorter HRT not enough to have the bacterial organic digestion while flow rates of 240 and $480 \mathrm{~L} / \mathrm{hr}$ could be somewhat slowly moving that might be induced heat conduction warming up water to inhibit the oxygen diffusion into subsurface water.

In facts, the water quality indicator itself can make some trouble to the another ones such as some short periods in changing of $\mathrm{pH}$, alkalinity, salinity, EC, temperature, and DO might be in non-linearity dominances to the organic digestion processes, particularly the interchanges among BOD and TDS, and also among $\mathrm{NH}_{4}-\mathrm{N}$, $\mathrm{NO}_{2}-\mathrm{Nand} \mathrm{NO}_{3}-\mathrm{N}$ due to unsteady processes of nitrification and denitrification (see Figure 6 and Table 3). It can be expressed that the recirculation aquaculture of Whiteleg shrimps in $3-\mathrm{m}^{3}$ concrete gutters containing ACM-Brick filters that the flow rate of $720 \mathrm{~L} / \mathrm{hr}$ is the most probable criteria for effective wastewater treatment rather than 240, 480, and $960 \mathrm{~L} / \mathrm{hr}$ due to HRT, bacterial organic digestion inhibitors, thermo-siphon process, and nitrogen compounds interchanging.

\subsection{Effective Numbers of ACM Check Dam}

The previous section concerning with ACM filters $(1 \times 1 \times 0.5 \mathrm{~m})$, the 2-inch-diameter chipped brick (red brick) was chosen as the most effective filter for recirculation aquaculture of Whiteleg shrimps in the concrete gutters in size of 3 cu.m. (1x1x3 m) as shown in Figure 2. Those case was subjected only one vertical filtration with $480 \mathrm{~L} / \mathrm{hr}$ flow rate rather than ACM check dam which emphasized on horizontal overflowing and/or flow-through the assembled-constructed-material spaces before moving from the head to the tip along 1:1,000 slope concrete-gutter beds. To make sure, the small chipped materials for constructing ACM check dams had to be rechecked in relation to its effective numbers and flow rates of wastewater recirculation for Whiteleg shrimp aquaculture.

After draining the influent through five ACM check dams as constructed by assembling the 2-inch-diameter chips of rocks, blocked cements, bricks, and roof-tiles in pyramid forms ( 45 degrees in front of dam axis at least 30 degrees in downstream portion) and control (no check dam), the results were presented in Table 4 which indicated the averaged BOD concentration as obtained from 3-consecutive experiments by draining with flow rates of 300 , 600,900 , and $1,200 \mathrm{~L} / \mathrm{hr}$. The averaged BOD in influents started up with range $12.17 \mathrm{mg} / \mathrm{L}$ to $12.40 \mathrm{mg} / \mathrm{L}$ after treating by ACM check dams1, 2, 3, 4, and 5 that tended to decrease in all kinds of constructed materials as used for ACM check dam construction in relation to flow rates but less decrease found in control concrete gutters (see Table 4). It was quite clear that the flow rates of $600 \mathrm{~L} / \mathrm{hr}$ and $900 \mathrm{~L} / \mathrm{hr}$ were indicated as the most probable discharges of influents through ACM check dams which came across on all kinds of constructed materials of ACM check dams, particularly ACM check dams 3, 4, and 5 as shown in Table 4. Seemingly, at least 3 ACM-Brick check 
dams should be employed for treating wastewater from Whiteleg shrimp farming together with flow rates between $600 \mathrm{~L} / \mathrm{hr}$ and $900 \mathrm{~L} / \mathrm{hr}$ due to the proper hydraulic retention time $(\mathrm{HRT})$, rather than 1,200 L/hr because of shorter $\mathrm{HRT}$, and $300 \mathrm{~L} / \mathrm{hr}$ according to longer HRT and warming wastewater by heat conduction. Another observing point on experiments found the BOD in treated Whiteleg shrimp farming wastewater after treating by the fifth ACM-Brick check dam at amount of 1.8 and $1.3 \mathrm{mg} / \mathrm{L}$ for flow rates of 600 and $900 \mathrm{~L} / \mathrm{hr}$, respectively while amount of 4.2 and $4.3 \mathrm{mg} / \mathrm{L}$ for flow rates in respecting to 600 and $900 \mathrm{~L} / \mathrm{hr}$ at the fourth ACM-Brick check dam, and also 6.5 and $6,4 \mathrm{mg} / \mathrm{L}$ at the third ACM-Brick check dam see Table 3). The former statements is concluded that at least 3 ACM-Brick check dams in concrete gutters can be employed to treat wastewater from Whiteleg shrimp culturing under the conditions of flow rate between 600 to $900 \mathrm{~L} / \mathrm{hr}$. The result (Table 5) was also pointed out that the more the ACM-Brick check dams were the more the treatment efficiency (Abou-Elela et al., 2010; Sah et al., 2011; Cohen et al., 2005; Khan et al., 2009).
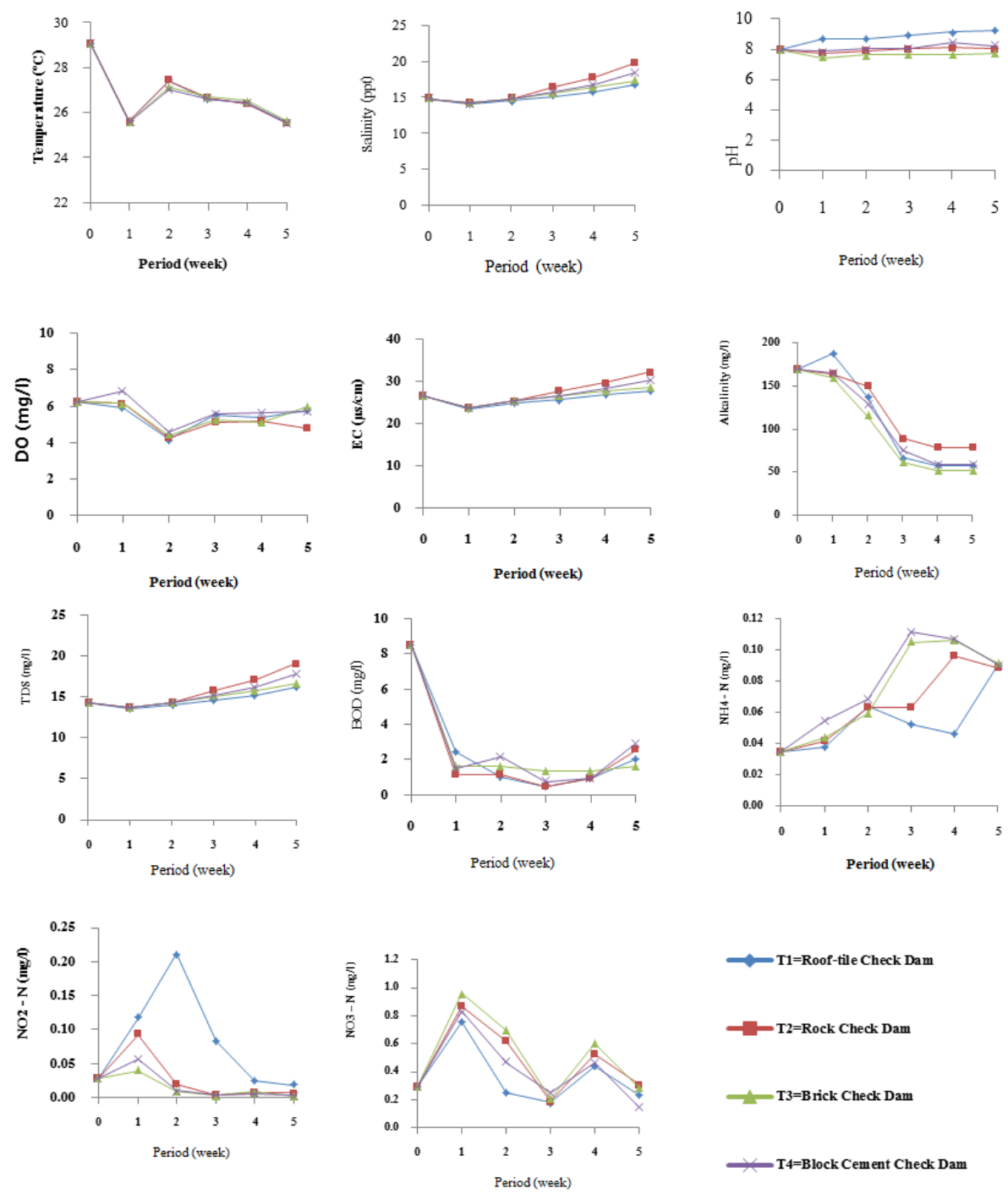

Figure 6. Relationships between 5-week culturing periods of Whiteleg shrimps in 3-cu.m.concrete gutters and water quality indicators

Table 3. Averaged water quality indicators during 5-week aquaculture of Whiteleg shrimps after passing through ACM-Brick filters in corresponding to flow rates of 240, 480, 720, and $960 \mathrm{~L} / \mathrm{hr}$

\begin{tabular}{|c|c|c|c|c|c|c|c|c|c|c|c|c|}
\hline \multirow[t]{2}{*}{ Flow Rate(L/hr) } & \multirow[t]{2}{*}{ week } & \multicolumn{11}{|c|}{ Water Quality } \\
\hline & & $\begin{array}{l}\text { Temp. } \\
\left({ }^{\circ} \mathrm{C}\right)\end{array}$ & $\begin{array}{c}\text { Salinity } \\
\text { (ppt) }\end{array}$ & $\mathrm{pH}$ & $\begin{array}{c}\mathrm{DO} \\
(\mathrm{mg} / \mathrm{L})\end{array}$ & $\begin{array}{c}\text { EC } \\
\text { (us/cm) }\end{array}$ & $\begin{array}{c}\text { Alkaline } \\
(\mathrm{mg} / \mathrm{L})\end{array}$ & $\begin{array}{c}\text { TDS } \\
(\mathrm{mg} / \mathrm{L})\end{array}$ & $\begin{array}{c}\text { BOD } \\
(\mathrm{mg} / \mathrm{L})\end{array}$ & $\begin{array}{l}\mathrm{NH}_{4}-\mathrm{N} \\
(\mathrm{mg} / \mathrm{L}) \\
\end{array}$ & $\begin{array}{l}\mathrm{NO}_{2}-\mathrm{N} \\
(\mathrm{mg} / \mathrm{L}) \\
\end{array}$ & $\begin{array}{l}\mathrm{NO}_{3}-\mathrm{N} \\
(\mathrm{mg} / \mathrm{L}) \\
\end{array}$ \\
\hline \multirow[t]{2}{*}{240} & 1 & 29.2 & 18.1 & 8.2 & 6.6 & 31.7 & 76.7 & 17.2 & 17.6 & 0.09 & 0.30 & 0.25 \\
\hline & 2 & 30.5 & 18.1 & 8.2 & 2.7 & 32.4 & 126.0 & 17.4 & 13.3 & 0.17 & 0.45 & 2.26 \\
\hline
\end{tabular}




\begin{tabular}{|c|c|c|c|c|c|c|c|c|c|c|c|c|}
\hline & 3 & 29.3 & 18.6 & 8.6 & 4.4 & 32.6 & 132.7 & 17.9 & 8.4 & 0.18 & 0.47 & 2.26 \\
\hline & 4 & 29.9 & 19.4 & 9.0 & 6.4 & 34.2 & 114.0 & 18.5 & 3.7 & 1.40 & 0.45 & 2.76 \\
\hline & 5 & 30.0 & 20.5 & 9.0 & 4.8 & 36.1 & 109.3 & 19.7 & 8.7 & 1.05 & 0.44 & 1.07 \\
\hline & 6 & 30.4 & 21.2 & 8.6 & 4.0 & 37.5 & 117.0 & 20.4 & 4.7 & 0.08 & 0.45 & 1.10 \\
\hline & 7 & 30.4 & 22.5 & 8.8 & 4.4 & 39.5 & 102.3 & 21.6 & 3.8 & 0.74 & 0.22 & 1.13 \\
\hline \multirow[t]{7}{*}{480} & 1 & 28.7 & 18.1 & 8.3 & 4.0 & 31.5 & 61.3 & 17.2 & 19.1 & 0.09 & 0.12 & 0.19 \\
\hline & 2 & 30.3 & 18.1 & 8.3 & 2.8 & 32.4 & 127.3 & 17.4 & 9.5 & 0.17 & 0.48 & 2.23 \\
\hline & 3 & 28.5 & 18.7 & 8.6 & 4.0 & 32.3 & 134.7 & 18.0 & 7.6 & 0.21 & 0.45 & 2.25 \\
\hline & 4 & 29.2 & 19.4 & 8.9 & 5.0 & 33.9 & 124.0 & 18.7 & 3.1 & 1.16 & 0.45 & 2.80 \\
\hline & 5 & 29.2 & 20.5 & 8.9 & 4.4 & 53.6 & 118.0 & 19.7 & 9.9 & 0.79 & 0.44 & 1.00 \\
\hline & 6 & 29.7 & 21.2 & 8.8 & 4.2 & 36.9 & 116.0 & 20.4 & 3.7 & 0.04 & 0.31 & 1.03 \\
\hline & 7 & 29.6 & 22.4 & 8.8 & 4.2 & 38.9 & 101.7 & 21.5 & 3.8 & 0.87 & 0.13 & 1.08 \\
\hline \multirow[t]{7}{*}{720} & 1 & 29.2 & 17.9 & 8.3 & 4.4 & 31.6 & 72.0 & 17.0 & 18.4 & 0.09 & 0.12 & 0.14 \\
\hline & 2 & 30.5 & 17.9 & 8.0 & 3.2 & 32.4 & 119.3 & 17.2 & 13.7 & 0.17 & 0.45 & 2.21 \\
\hline & 3 & 29.2 & 18.5 & 8.4 & 4.2 & 32.5 & 124.7 & 17.9 & 6.6 & 0.24 & 0.46 & 2.31 \\
\hline & 4 & 29.8 & 19.4 & 8.8 & 4.2 & 34.2 & 111.3 & 18.6 & 3.1 & 1.09 & 0.44 & 2.96 \\
\hline & 5 & 29.3 & 20.4 & 8.8 & 5.0 & 35.8 & 113.3 & 19.6 & 6.2 & 0.81 & 0.41 & 1.11 \\
\hline & 6 & 30.3 & 21.1 & 8.7 & 4.3 & 37.4 & 117.3 & 20.3 & 3.3 & 0.05 & 0.25 & 1.19 \\
\hline & 7 & 30.2 & 22.5 & 8.6 & 4.1 & 39.4 & 99.3 & 21.6 & 2.8 & 0.97 & 0.09 & 1.12 \\
\hline \multirow[t]{7}{*}{960} & 1 & 29.2 & 18.2 & 8.3 & 5.3 & 31.9 & 74.0 & 17.3 & 19.4 & 0.10 & 0.12 & 0.20 \\
\hline & 2 & 30.1 & 18.2 & 7.9 & 3.6 & 32.4 & 138.7 & 17.4 & 11.7 & 0.17 & 0.44 & 2.29 \\
\hline & 3 & 28.6 & 18.8 & 8.5 & 4.4 & 32.4 & 138.0 & 18.0 & 5.6 & 0.27 & 0.45 & 2.30 \\
\hline & 4 & 29.2 & 19.5 & 8.8 & 4.1 & 34.0 & 118.7 & 18.8 & 1.9 & 1.48 & 0.45 & 2.95 \\
\hline & 5 & 29.2 & 20.5 & 8.9 & 6.4 & 35.6 & 115.0 & 19.7 & 11.3 & 1.24 & 0.43 & 1.09 \\
\hline & 6 & 29.6 & 20.9 & 8.7 & 4.2 & 37.0 & 114.7 & 20.4 & 2.8 & 0.08 & 0.38 & 1.21 \\
\hline & 7 & 29.6 & 22.5 & 8.7 & 4.3 & 39.0 & 99.0 & 21.6 & 3.4 & 1.91 & 0.13 & 1.10 \\
\hline
\end{tabular}

Table 4. Average BOD Concentration of Whileleg Shrimp Wastewater after Treating by Check Dam $1: 6$

\begin{tabular}{|c|c|c|c|c|c|c|c|c|c|c|c|c|c|c|c|c|c|c|c|c|c|c|c|c|c|c|}
\hline \multirow[b]{2}{*}{ 岂 } & \multirow[b]{2}{*}{ 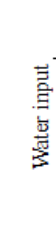 } & \multicolumn{5}{|c|}{ Check Dam 1} & \multicolumn{5}{|c|}{ Check Dam 2} & \multicolumn{5}{|c|}{ Check Dam 3} & \multicolumn{5}{|c|}{ Check Dam 4} & \multicolumn{5}{|c|}{ Check Dam 5} \\
\hline & & 능 & 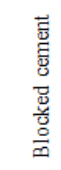 & 总 & 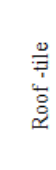 & 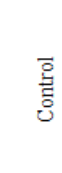 & 능 & 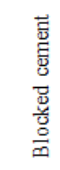 & 总 & 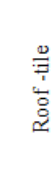 & 官 & $\begin{array}{l}\text { 등 } \\
\end{array}$ & 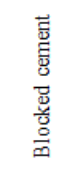 & 总 & $\begin{array}{l}\stackrel{0}{\Xi} \\
\stackrel{\Xi}{\Xi} \\
\stackrel{0}{\Xi}\end{array}$ & 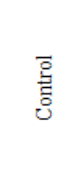 & 늠 & 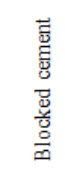 & 总 & $\begin{array}{l}\stackrel{0}{\exists} \\
\stackrel{\Xi}{0} \\
\vdots\end{array}$ & $\begin{array}{l}\overline{0} \\
\text { 词 }\end{array}$ & 능 & 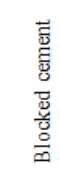 & 总 & 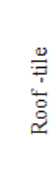 & $\begin{array}{l}\text { 홀 } \\
\text { 范 }\end{array}$ \\
\hline 300 & 12.2 & 11.2 & 11.8 & 11.4 & 11.4 & 11.8 & 10.7 & 11.3 & 9.8 & 10.6 & 11.4 & 10.3 & 9.7 & 8.9 & 9.4 & 10.8 & 9.1 & 9.1 & 7.4 & 8.3 & 10.6 & 7.7 & 7.1 & 6.6 & 7.3 & 10.3 \\
\hline 600 & 12.4 & 10.9 & 11.0 & 10.8 & 11.9 & 11.9 & 9.5 & 9.3 & 9.8 & 9.7 & 11.4 & 7.6 & 7.4 & 6.5 & 7.1 & 10.9 & 5.1 & 5.4 & 4.2 & 4.0 & 10.4 & 3.1 & 2.8 & 1.8 & 2.5 & 9.7 \\
\hline 900 & 12.2 & 10.6 & 11.0 & 10.6 & 11.4 & 12.2 & 8.7 & 10.1 & 9.4 & 10.4 & 10.6 & 0.6 & 8.4 & 6.4 & 8.7 & 9.9 & 5.0 & 6.6 & 4.3 & 7.1 & 9.8 & 3.7 & 5.1 & 1.3 & 4.7 & 9.7 \\
\hline 1200 & 12.4 & 12.1 & 12.2 & 12.0 & 12.0 & 12.2 & 11.7 & 11.6 & 9.9 & 10.1 & 11.0 & 11.3 & 11.1 & 8.4 & 8.8 & 10.7 & 11.3 & 10.3 & 6.7 & 7.6 & 10.6 & 9.0 & 8.7 & 4.3 & 6.2 & 10.4 \\
\hline
\end{tabular}

Table 5. BOD in Whileleg Shrimp Wastewater Treatment Efficiency after Treating by ACM Check Dam (\%)

\begin{tabular}{|c|c|c|c|c|c|c|c|c|c|c|c|c|c|c|c|c|c|c|c|c|c|c|c|c|c|c|}
\hline \multirow[b]{2}{*}{ 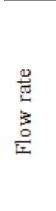 } & \multirow[b]{2}{*}{ 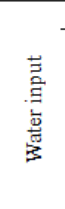 } & \multicolumn{5}{|c|}{ Check Dam 1} & \multicolumn{5}{|c|}{ Check Dam 2} & \multicolumn{5}{|c|}{ Check Dam 3} & \multicolumn{5}{|c|}{ Check Dam 4} & \multicolumn{5}{|c|}{ Check Dam 5} \\
\hline & & 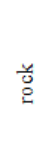 & 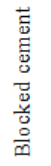 & $\begin{array}{l}\frac{.}{0} \\
\frac{0}{0}\end{array}$ & 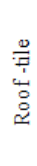 & $\begin{array}{l}\overline{8} \\
\text { 吾 } \\
\text { d }\end{array}$ & 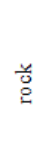 & 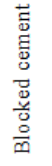 & 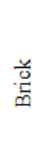 & 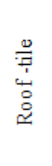 & 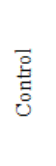 & 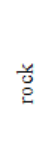 & 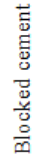 & 弟 & 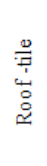 & 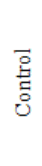 & 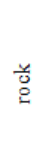 & 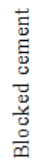 & $\begin{array}{l}\text { 总 } \\
\text { 品 }\end{array}$ & $\begin{array}{l}\stackrel{0}{7} \\
\frac{1}{\circ} \\
\stackrel{0}{0}\end{array}$ & 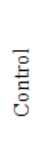 & $\begin{array}{l}\text { 을 } \\
\text { ㅇ․ }\end{array}$ & 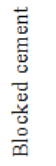 & 晜 & $\begin{array}{l}\frac{\omega}{7} \\
\frac{1}{\circ} \\
\stackrel{\circ}{\circ}\end{array}$ & $\begin{array}{l}\overline{\mathrm{g}} \\
\text { 뭉 }\end{array}$ \\
\hline 300 & 12.17 & 7.8 & 3.2 & 6.4 & 6.0 & 3.5 & 4.5 & 3.8 & 13.7 & 7.8 & 2.8 & 4.1 & 14.7 & 9.0 & 11.1 & 5.8 & 11.4 & 5.7 & 16.8 & 11.2 & 1.6 & 15.2 & 22.0 & 11.2 & 12.7 & 2.4 \\
\hline 600 & 12.40 & 12.3 & 11.6 & 13.0 & 4.2 & 3.7 & 12.3 & 15.6 & 9.3 & 18.2 & 4.2 & 20.5 & 19.8 & 34.0 & 26.6 & 4.9 & 32.4 & 27.0 & 34.8 & 43.9 & 4.0 & 39.8 & 49.2 & 56.4 & 36.5 & 7.2 \\
\hline 900 & 12.20 & 13.4 & 9.6 & 13.1 & 6.8 & 0.4 & 17.4 & 8.8 & 11.3 & 8.2 & 13.2 & 24.0 & 16.9 & 31.6 & 16.6 & 6.2 & 24.1 & 21.5 & 33.7 & 18.8 & 1.0 & 27.2 & 22.8 & 69.5 & 33.5 & 1.0 \\
\hline 1200 & 12.40 & 2.4 & 1.3 & 3.5 & 3.0 & 1.6 & 3.0 & 5.2 & 17.0 & 16.1 & 10.2 & 3.4 & 4.6 & 15.4 & 12.9 & 2.3 & 0.3 & 6.6 & 20.6 & 13.3 & 1.4 & 20.1 & 15.5 & 35.5 & 19.2 & 1.4 \\
\hline
\end{tabular}


Table 6. Averaged weight, length, and cultural products of Whiteleg shrimp aquaculture by 3-cu.m. concrete gutters in relation to density from beginning until harvesting for 3-month periods (8 June 2010 to 20 August 2010)

\begin{tabular}{|c|c|c|c|c|c|c|c|c|c|c|c|c|c|}
\hline \multirow{2}{*}{\multicolumn{3}{|c|}{$\begin{array}{c}\text { Beginning of Juveniles } \\
\text { Releasing }\end{array}$}} & \multicolumn{6}{|c|}{ weight and Length } & \multicolumn{5}{|c|}{ Harvesting Products } \\
\hline & & & & & & & & & & & & & \\
\hline \multirow{3}{*}{$\begin{array}{l}\text { Density/ } \\
3 \mathrm{~m}^{2}\end{array}$} & \multicolumn{2}{|c|}{ Total weight } & \multicolumn{5}{|c|}{ weight ,g/shrimp } & \multirow{2}{*}{$\begin{array}{c}\text { Length } \\
\qquad \\
\mathrm{cm}\end{array}$} & \multirow{3}{*}{$\begin{array}{c}\text { Survuiva } \\
1 \\
\text { shrimps/ } \\
3 \mathrm{~m}^{2}\end{array}$} & \multicolumn{2}{|c|}{$\begin{array}{c}\text { Production } \\
\text { Weight }\end{array}$} & \multicolumn{2}{|c|}{ Added Weight } \\
\hline & \multirow[t]{2}{*}{$\mathrm{Kg} / \mathrm{m}^{2}$} & \multirow[t]{2}{*}{$\mathrm{kg} / \mathrm{ha}$} & $24 / 6 / 201$ & 9/7/201 & $25 / 7 / 201$ & $9 / 8 / 201$ & $24 / 8 / 201$ & & & $\mathrm{Kg} / \mathrm{m}^{2}$ & $\mathrm{~kg} / \mathrm{ha}$ & $\mathrm{Kg} / \mathrm{h}$ & $\%$ \\
\hline & & & 0 & 0 & 0 & 0 & 0 & & & & & $\mathrm{a}$ & \\
\hline \multirow[t]{2}{*}{105} & 0.3896 & 3,896 & 11.13 & 14.29 & 16.24 & 21.03 & 22.52 & 15.4 & 88 & 0.6606 & 6,606 & 2,710 & 69.5 \\
\hline & & & & & & & & & & & & & 5 \\
\hline \multirow[t]{2}{*}{175} & 0.6720 & 6,720 & 11.52 & 11.97 & 15.66 & 19.16 & 22.67 & 15 & 147 & 1.1108 & 11,108 & 4,388 & 65.2 \\
\hline & & & & & & & & & & & & & 9 \\
\hline \multirow[t]{2}{*}{245} & 0.8371 & 8,371 & 10.25 & 12.75 & 15.53 & 17.65 & 20.09 & 14.2 & 183 & 1.2255 & 12.255 & 3,884 & 46.3 \\
\hline & & & & & & & & & & & & & 9 \\
\hline \multirow[t]{2}{*}{315} & 1.1382 & 11,382 & 10.84 & 12.78 & 15.05 & 16.47 & 18.34 & 15 & 265 & 1.6200 & 16,200 & 4,800 & 42.3 \\
\hline & & & & & & & & & & & & & 3 \\
\hline
\end{tabular}

\subsection{Applicable ACM-Brick Check Dams for Whiteleg Shrimp Aquaculture}

It was understandable from former experiments on selected ACM-Brick filters as the most proper device for wastewater treatment from Whiteleg shrimp aquaculture. Thus, the following description would pay more attention on using $0.5 \mathrm{~m}^{3} \mathrm{ACM}$-Brick filters to treat such wastewater for recirculation aquaculture in concrete gutters in size of $3 \mathrm{~m}^{3}(1 \times 1 \times 3 \mathrm{~m})$ under the densities of $105,175,245$, and 315 juveniles $/ 3 \mathrm{~m}^{3}$ (4 treatments and 3 replications) together with flow rates of $720 \mathrm{~L} / \mathrm{hr}$ as illustrated in Figure 4.

It was understandable from former sections concerning with selecting the ACM-Brick filters in concrete gutters as devices for wastewater treatment through recirculation aquaculture of Whileleg shrimp aquaculture. The beginning weight of juvenile Whiteleg shrimps per 3-sq.m.concrete gutters equivalent to $1.1688 \mathrm{~kg}(3,896 \mathrm{~kg} / \mathrm{ha})$, $2.0160 \mathrm{~kg}(6,720 \mathrm{~kg} / \mathrm{ha}), 2.5113 \mathrm{~kg}(8.371 \mathrm{~kg} / \mathrm{ha})$, and $3.4146 \mathrm{~kg}(11,382 \mathrm{~kg} / \mathrm{ha})$ for $105,175,245$, and 315 juveniles per 3 sq.m., respectively. After culturing for 3 -month periods, the harvesting products found 6,600 $\mathrm{kg} / \mathrm{ha}, 11,108 \mathrm{~kg} / \mathrm{ha}, 12,255 \mathrm{~kg} / \mathrm{ha}$, and $16,200 \mathrm{~kg} / \mathrm{ha}$ in which the added weight was produced as $2,710,4,388$, 3,884 , and $4,800 \mathrm{~kg} / \mathrm{ha}$ in relation to $105,175,245$, and 315 Whiteleg shrimps as cultured in 3-sq.m.concrete gutters with 1-m depth (see Table 6). To ensure the research findings, the added weights as gained from releasing juveniles for 3-month culturing were calculated in percentages of beginning weight and found as $69.55 \%$, $65.29 \%, 46.30 \%$, and $42.33 \%$ for densities of $105,175,245$, and 315 juveniles in 3-cu.m concrete gutters, respectively. The percentages of added weight after culturing Whiteleg shrimps for 3-month period were obviously indicated that the more the densities of Whiteleg shrimp aquaculture resulted the very less the product which were similar almost as the studies of Wu \& Yang (2011), Cahu et al. (2012), Casillas-Hernandez et al. (2007), Mariscal-Lagarda et al. (2012), Xu et al. (2012), Carvalho et al. (2013), and Hai \& Yakupitiyage (2005).

\section{Conclusion}

Owing to the research is attempted to recirculate the treated wastewater from Whiteleg shrimp culturing in following each other without interruption by using concrete gutter containing ACM check dams as the filters, details as follows:-

1) Employing 3.5- $\mathrm{m}^{3}$ concrete gutters including $0.5 \mathrm{~m}^{3}$ filters by filling assembled-constructed materials (ACM) among 2-inch chips of roof-tile, rock, brick, and blocked cement under RCB design with 4 treatments and 3 replications in corresponding to flow rates of $240,480,720$, and $960 \mathrm{~L} / \mathrm{hr}$. Results found ACM-Brick filter as the most probable device together with flow rates of $720 \mathrm{~L} / \mathrm{hr}$.

2) Employing 12-m length and 1x1-sq.m. X-sectional area of concrete gutters containing 5 ACM check dams with 5-m space for recking ACM (roof-tile, rock, brick, and blocked cement) and determining the minimum numbers of dams under the flow rates of 300,600, 900, and $1200 \mathrm{~L} / \mathrm{hr}$. The results still found ACM-Brick check dam was the most effective material for wastewater treatment of Whiteleg shrimp aquaculture, and proper flow rate of 600-900 L/hr was high efficiency for recirculation aquaculture.

3) Employing $3 \mathrm{~m}^{3}$ concrete gutters containing only one of $0.5 \mathrm{~m}^{3}$ ACM-Brick filters for treating wastewater of Whiteleg shrimp culturing under flow rates of $720 \mathrm{~L} / \mathrm{hr}$ as the most effective aquaculture circulation in terms of 
organic waste elimination rather than 240,480 and $960 \mathrm{~L} / \mathrm{hr}$. Nevertheless, culturing Whiteleg shrimps in the conditions of high efficiencies of ACM-Brick filters and continuously flow rates with density of 105 juveniles per $3 \mathrm{~m}^{3}(6,606 \mathrm{~kg} / \mathrm{ha})$ gained benefits more $69.55 \%$ of beginning weight, while densities of $11,108 \mathrm{~kg} / \mathrm{ha}$, $12,255 \mathrm{~kg} / \mathrm{ha}$, and $16,200 \mathrm{~kg} / \mathrm{ha}$ with corresponding to obtained benefits of $65.29 \%, 46.39 \%$, and $42.33 \%$, respectively. In other words, the less the density of Whiteleg shrimp culturing provide the more the products.

\section{Acknowledgement}

We are thankful to staffs of The King's Royally Initiative Laem Phak Bia Research and Development Project for their supporting. We are also in debt to The Chaipattana Foundation for conducting and funding this study. We would like to give thanks to the Eco-Science Community Research Group (ESCRG), Department Environmental Science, Faculty of Environment, Kasetsart University for facilitating the personnel and laboratories.

\section{References}

Abou-Elela, S. I., Kamel, M. M., \& Fawzy, M. E. (2010). Biological treatment of saline wastewater using a salt-tolerant microorganisms. Desalination, 250, 1-5. http://dx.doi.org/10.1016/j.desal.2009.03.022

Andrian, D. D., \& Sanders, T. G. (1998). Oxygen Sag equation for second-order BOD decay. Water Research, 32, 840-848. http://dx.doi.org/10.1016/S0043-1354(97)00259-5

APHA, AWWA, WEF. (2005). Standard Methods for the Examination of water and Wastewater (21st ed.) American Public Health Association, Washington, USA.

Borkar, R. P., \& Mahatme, P. S. (2011). Wastewater treatment with vertical flow constructed wetland. International Journal of Environmental Science, 2(2), 590-603.http://dx.doi.org/10.6088/ijes.00202020020

Burford, M. A., Thompson, P. J., McIntosh, R. P., Bauman, R. H., \& Pearson, D. C. (2004). The contribution of flocculated material to shrimp (Litopenaeus vannamei) nutrition in a high-intensively zero-exchange system. Aquaculture, 232, 525-537. http://dx.doi.org/10.1016/S0044-8486(03)00541-6

Cahu,T. B., Mendes, S. D. A., Cordula, C. R., Chavante, S. F., Carvaho, L. B., Nader, H. B., \& Bezerra, R. S. (2012). Recovery of protein,chitin,carotenoids,and glycosaminoglycans from Pacific white shrimp (Litopenaeus vannamei) processing waste. Process Biochemistry, 47, 570-577. http://dx.doi.org/10.1016/j.procbio.2011.12.012

Carvalho, R. A., Lemos, P. L. F., \& Tacon, A. G. J. (2013). Performance of single-drain and dual-drain tanks in terms of water velocity profile and solids flushing for in vivo digestibility studies in juvenile shrimp. Aquaculture Engineering, 57, 917. http://dx.doi.org/10.1016/j.aquen.2013.05.004.

Casillas-Hernandez, R., Nolaco-Soria, H., Garcia-Galano, T., Corrillo-Favnes, O., \& Pay-Osuma, F. (2007). Water quality, chemical fluxes and production in semi-intensive Pacific white shrimp (Litopenaeus vannamei) culture ponds utilization two different feeding stratigies. Aquaculture Engineering, 36, 105-114. $\mathrm{http}: / / \mathrm{dx}$.doi.org/10.1016/j.aquaeng.2006.09.04

Chuankao, K., Tarnchalanukit, W., Prabuddham, P., Phewnil, O., Bualert, S., Duangmal, K., Pattamapitoon, T., \& Nimpee, C. (2014). H.M. The King's Royally Initiated LERD Project on Community Wastewater Treatment through Small Wetlands and Oxidation Pond in Phetchaburi, Thailand. Modern Applied Science, 8(5), 223-246. http://dx.doi.org/10.5339/mas.v8n5p233.

Chunkao, K., Nimpee, C., \& Duangmal, K. (2012). The King's initiative using water hyacinth to removing heavy metals and plant nutrients from wastewater through Bueng Makkasan in Bangkok Thailand. Ecologictal Engineering, 39, 40-52. http://dx.doi.org/10.1016/j.ecoleng.2011.09.006

Clesceri, L. S., Greenberg, A. E., \& Eaton, A. D. (1998). Standard Methods for the Examination of Water and Wastewater (20th ed.). American Public Health Association, Washington, D.C.

Cohen, J. M., Samocha, T. M., Fox, J. M., Gandy, R. L., \& Lawrence, A. L. (2005). Characterization of water quality factors during intensive raceway production of juvenile Litopenaeus vannamei using limited discharge and biosecure management tools. Aquacultural Engineering, 32, 425-442. http://dx.doi.org/10.1016/j.aquaeng.2004.09.005

Cohen, J. M., Samocha, T. M., Fox, J. M., Grandy, R. L, \& Lawrence, A. L. (2005). Characterization of water quality factors during intensive race way production of juvenile Litopenaeus vannamei using limiting dicharge and biosecure management tools. Aquaculture Engineering, 32, 425-442. http://dx.doi.org/10.1016/j.aquaeng.2004.09.005

Erler, D., \& Pollard, P. C. (2004). Effects of second crops on bacterial growth and nitrogen removal in shrimp 
farm effluent treatment systems. Aquaculture Engineering, $\quad 30, \quad 103-114$. http://dx.doi.org/10.1016/j.aquaeng.2003.09.003

Green, B., \& Ward, G. H. (2011). Ultimate biochemical oxygen demand in semi-intensively managed shrimp pond waters. Aquaculture, 319, 253-261. http://dx.doi.org/10.1060/j.aquaculture.2011.06.031

Hai, T. N., \& Yakupitiyage, A. (2005). The effects of the composition of mangrove leaf litter on water quality, growth and survival of black tiger shrimp (Penaeus monodon Fabricius, 1789). Aquaculture, 250, 700-712. http://dx.doi.org/10.1016/j.aquaculture.2005.04.068

Khan, S. I., Ahmad, I., Shah, M. T., Rehman, S., \& Khalig, A. (2009). Use of constructed wetland for the removal of heavy metals from industrial wastewater. Journal of Environmental Management, 90, 3451-3457. http://dx.doi.org/10.1016/j.jenvman.2009.05.026

Lavania-baloo, S., Azman, M., Said, I. M., Ahmad, F., \& Mohamad, M. (2014). Biofiltration potential of macralgae for ammonia removal in outdoor tank shrimp wastewater recirculation system. Biomass and Bioenergy, 66, 103-109. http://dx.doi.org/10.1016/j.biombioe.2014.02.031

Mariscal-Lagarda, M. M., Paez-Osuna, F., Esquer-Mendez, J. L., Guerrero-Monroy, I., del Vivar, A. R., \& Felix-Gastrlis, R. (2012). Integrated culture of whiteleg shrimp (Litopenaeus vannamei) and tomato (Lycopersicon escuentum Mill.) with low salinity groundwater: Management and production Aquaculture, 366, 76-84. http://dx.doi.org/10.1060/j.aquacultuture.2012.09.003

Martins, C. I. M., Eding, E. H., Verdegem, M. C. J., Heinsbroek, L. T. N., Schneider, O., Blancheton, J. P., d'Orbcastel, E. R., \& Verreth, J. A. J. (2010). New developments in recirculating aquaculture system in Europe: A perspective on environmental sustainability. Aquacultural Engineering, 43, 83-93. http://dx.doi.org/10.1016/j.aquaeng.2010.09.002

Metcalf \& Eddy Inc. (1974). Wastewater Engineering: Collection, Treatment, Disposal. Tata McGrow-Hill Publishing Company Ltd., New Delhi.

Mispagel, H., \& Gray, J. T. (2005). Antibiotic resistance from wastewater oxidation ponds. Water Environment Research, 7, 2996-3002.http://dx.doi.org/10.2175/106143005x73901

Mook, W. T., Chakrabarti, M. H., Aroua, M. K., Khan, G. M. A., Khan, B. S., Ali, B. S., Islam, M. S., \& Hasan, M. A. A. (2012). Removal of total ammonia nitrogen (TAN), nitrate and total organic carbon (TOC) from aquaculture wastewater using electrochemical technology: A review. Desalination, 285, 1-13. http://dx.doi.org/10.1016/j.desal.2011.09.029

Padgett, W. J. (1975). Stochastic model for stream pollution. Mathematical Bioscience, 25, $309-317$. http://dx.doi.org/10.1016/0025-5564(75)90008-5.

Padgett, W. J. (1978). A stream-pollution model with random deoxygenation and reaeration coefficients. Mathematical Bioscience, 42, 137-148. http:www/dx.doi.org/10.1016/0025-5564(78)90011-1

Phewnil, O., Chaukao, K., Pattamapitoon, T., Intaraksa, A., Chueawong, O., Chantrasoon, C., \& Bonprakong, T. (2014). Choosing Aquatic Plant Species for High Wastewater Treatment Efficiency through Small Wetland. Modern Applied Science, 8(4), 187-194. http:www/dx.doi.org/10.5539/mas.v8n4p187

Prapaiwong, N., \& Boyd, C. E. (2012). Effluent volume and pollutant loads at an inland, low-salinity, shrimp farm in Alabama. Aquacultural Engineering, 48, 1-5. http:www/dx.doi.org/10.1016/aquaeng.2011.2004

Sah, L., Rousseau, D. P. L., Hooijimans, C. M., \& Lens, P. N. L. (2011). 3 -D model for a secondary facultative pond. Ecological Model, 222, 1592-1603. http://dx.doi.org/10.1016/0025-5564(78)90011-1

Sklarz, M. Y., Gross, A., Yakirevich, A., \& Soares, M. I. M. (2009). A recirculating vertical flow constructed wetland for treatment of domestic wastewater. Desalination, 246, 617-624. http://dx.doi.org/10.1016/j.desal.2008.09.002

Sridhar, B. B. M., Vincent, R. K., Roberts, S. J., \& Czajkowski, K. (2011). Remote sensing of soybean stress as an indicator of chemical concentration of biosolid amended surface soils. International Journal of Applied Earth Observation and Geoinformation, 13, 676-681. http://dx.doi.org/10.1016/j.jag.2011.04.005

Srivastav, R. C., \& Avasthi, P. K. (1975). Non-equilibrium thermodynamics of thermo-osmosis of water through kaoline. Journal of Hydrology, 24, 111-120. http://dx.doi.org/10.1016/0022-1694(75)90145-6

Streeter, H. W., \& Phelps, E. B. (1925). A study of the Pollution and Natural Purification of the Ohio River. Bulletin number 146. US Public Health Service, USA. 
Tchnobanoglous, G., \& Kreiti, F. (2002). Handbook of Solid Waste Management (2nd ed.). McGraw-Hill Inc., New York.

Tilley, D. R., Badrinarayanan, H., Rosati, R., \& Son, J. (2002). Constructed wetlands as recirculation filters in

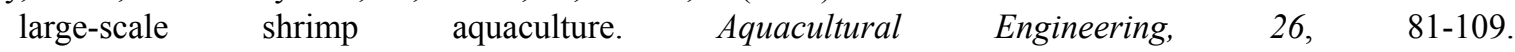
http://dx.doi.org/10.1016/S0144-8609(02)00010-9

Uwidia, I. E., \& Ademoroti, C. M. A. (2012). Correlation of five-day BOD and SS concentration in wastewater. Nigerian Journal of Science, 30, 19-127.

Uwidia, I. E., \& Ukulu, H. S. (2013). Studies on electrical conductivity and obtained from an estate in Warri, Nigeria. Greener Journal of Physical Science, 3, 110-114.

Vymazal, J. (2010). Constructed wetlands for wastewater treatment. Water, 2, 530-549. http:www.dx.doi.org/10.3390/w2030530.

Wu, X. Y., \& Yang, Y. F. (2011). Heavy metal (Pb, Co, Cd, Cr, Cu, Mn, and Zn) concentrations in harvest-size white shrimp Litopenaeus vannamei tissues from aquaculture and wild source. Journal of Food Composition and Analysis, 24, 62-65. http:www.dx.doi.org/10.1016/j.j.fca.2010.03.030

Xu, W. J., Pan, L. Q., Zhao, D. H., \& Huang, L. (2012). Preliminary investigation into the contribution of bioflocs on protein nutrient of Litopenaeus vannamei fed with different dietary protein levels in zero-water $\begin{array}{llll}\text { exchange culture } \quad \text { Ankaculture, } & \text { 353-355, }\end{array}$ http:www.dx.doi.org/10.1016/j.aquaculture.2012.04.003

\section{Copyrights}

Copyright for this article is retained by the author(s), with first publication rights granted to the journal.

This is an open-access article distributed under the terms and conditions of the Creative Commons Attribution license (http://creativecommons.org/licenses/by/3.0/). 